\title{
A FEJLESZTŐ ÉRTÉKELÉS MÓDSZERTANA
}

\section{GYÖRFYNÉ KUKODA ANDREA}

\author{
a Nemzeti Közszolgálati Egyetem Közigazgatás-tudományi Karának \\ tanársegéde \\ gyorfyne.kukoda.andrea@uni-nke.hu
}

Lénárd Sándor és Rapos Nóra szerzőpáros Fejlesztő értékelés címü könyvének megírását a szerzők fő kutatási területének, az adaptív oktatás és az arra épülő új pedagógiai értékelési szemlélet, a fejlesztő értékelés értelmezésének igénye inspirálta. A két szerző kutatási területe több ponton érintkezik egymással, közös témájuk az adaptív oktatás és a fejlesztő értékelés. Lénárd Sándor önálló kutatási területe ezeken felül a szociális kompetencia és a pedagógus nézetek; Rapos Nóráé pedig a kooperatív tanulás, az iskolai félelmek és a neveltségi szint. A szerzőpáros korábban is több közös publikációt jelentetett meg az adaptív oktatás, adaptív tanulásszervezés és a fejlesztő értékelés témájában.

A Fejlesztő értékelés című könyv a Gondolat Kiadó Oktatás-módszertani Kiskönyvtár címủ sorozatában jelent meg, több új oktatási módszerrel (mint például a projektoktatással, a problémaközpontú csoportmunka témakörével, a portfólióval, mint oktatási módszerrel stb.) foglalkozó kiadvánnyal egyetemben. Noha a szemlézett kiadvány már közel négy éve jelent meg, de azóta semmit sem vesztett aktualitásából. A kötet számos előzményre alapoz, mely közül a legfontosabb az a módszertani füzet, mely egy holland-magyar közremüködésben zajló iskolafejlesztési program (MAG: Megelőzés - Alkalmazkodás - Gondoskodás) egyik köteteként (MAGTÁR III) az adaptív tanulásszervezéshez szorosan kapcsolódó fejlesztő értékelés témakörét érintette. Ezen program kutatási eredményeire alapozva, azt továbbfejlesztve töltötték meg a szerzők új tartalommal könyvüket. $A$ mü elsödleges célja a fejlesztö értékelés fogalmának értelmezésén és fejlödéstörténetének bemutatásán túl, módszertani ötletek szolgáltatása a mindennapi pedagógiai gyakorlat számára, közvetlen ,jó példák”, ,jó gyakorlatok” ismertetésén keresztül. A szerzők gondolatébresztőnek szánt, de akár azonnal is hasznosítható ábrák, munkalapok és táblázatok széles kínálatával nyújtanak segítséget a fejlesztő értékelés szemléletével ismerkedők, illetve azt a pedagógia gyakorlatába bevezetni törekvők számára.

Az iskolai értékelés szakirodalma rendkívül gazdag. Már a hatvanas évek végén Scriven (Scriven, 1967) markánsan elkülönítette a pedagógiai értékelés három alapfunkcióját (diagnosztikus/helyzetfeltáró, formatív/a tanulási folyamatot segítő, szummatív/lezáró, minősítö), melyeket hazánkban a pedagógusok döntően Báthory 
Zoltán munkássága révén ismerhettek meg (Báthory, 1997). Az elmúlt évtizedekben a szervezett és differenciált pedagógiai értékelés tudományos kutatásának több szakasza volt megkülönböztethető, melyek során a pedagógiai értékelés szintjeinek differenciálódásával párhuzamosan az értékelési témák és funkciók is összetettebbé váltak. Az 1980-as évek közepétől a kompetencia alapú oktatás igénye, az egész életen át tartó tanulás stratégiája előtérbe helyezte a tanulási képességek fejlesztését és értékelését egyaránt. A tanulás folyamatában nagyobb hangsúlyt kapott az önfejlesztés, az önértékelés, az egyéni stratégiák fejlesztése (önszabályozó tanulás). Ezek a kihívások a fejlesztő értékelés reneszánszát eredményezték szerte a világon (Brassói, Hunya és Vass, 2005).

A hazai és a nemzetközi szakirodalom (Scriven nyomán) általában háromféle értékelési módot különböztet meg: a minősítő értékelést (teljesítménymérést), a diagnosztikai értékelést és a fejlesztő értékelést (Golnhofer, 2003). A fejlesztő értékelés a scriveni formatív értékelési formához áll legközelebb, annak egy továbbfejlesztett változata (Vidákovich, 2005). Nagy előnye, hogy magát a tanulási folyamatot segíti, formálja. Az értékelés lényege maga a fejlesztés, hiszen a diákoknak az értékelésben betöltött aktív szerepe, valamint a folyamatos visszajelzés a tanulók énképére, önfejlesztésére, önértékelésére is hat. Az OECD definíciója szerint: „a fejlesztő értékelés a tanulók fejlődésének és tudásának gyakori, interaktív módon történő értékelését jelenti, célja a tanulási célok meghatározása és a tanítás azokhoz igazítása" $\left(O E C D\right.$ CERI, 2005) ${ }^{1}$. A fejlesztő értékelés gyakorlatban történő alkalmazására, hatékonyságának igazolására a nemzetközi szakirodalomban számos példát találhatunk, elsősorban olasz, dán, kanadai területeken (Brassói, Hunya és Vass, 2005), de egyre több kutatás irányul Magyarországon is a megvalósuló ,jó gyakorlatok" vizsgálatára (pl. MAG program).

A Lénárd-Rapos szerzőpáros könyvének bevezetöjében utal a fejlesztő értékelés kutatásának előzményeire, valamint összefoglalóan közli a módszertani kiadvány céljait, törekvéseit, ismerteti a kötet föbb csomópontjait.

A mü első fejezete a fejlesztő értékelés elméleti szempontjait tekinti át. Az értékelést, mint rendszerelemet helyezi el a tanítási-tanulási folyamat komplex rendszerében, utalva az értékelés szerepének történeti alakulására, a gyermekfelfogás változása, a tanítás-tanulás paradigma újrafogalmazása és az iskola funkciójának időbeli változása tükrében. Rövid összefoglalást olvashatunk a fejlesztő értékelés előzményeiről, kiemelve a Scriven által megfogalmazott három értékelési alapfunkció lényegét és szerepének változását. Áttekintést kapunk egy a '90-es években Angliában folytatott, a formatív értékelés vizsgálatára irányuló kutatásról, mely elvezetett a formatív és a fejlesztő értékelés fogalmának megkülönböztetésé-

\footnotetext{
${ }^{1}$ In: Lénárd Sándor - Rapos Nóra (2009): Fejlesztő értékelés. Gondolat Kiadó, Budapest, 20. p. Fejlesztő értékelés. A tanulást fejlesztő osztálytermi módszerek a középfokú oktatásban (2005): OECD CERI. Országos Közoktatási Intézet, Budapest. URL: http://www.oki.hu/oldal.php?tipus=kiadvany\& kod=fejleszto Letöltés ideje: 2015.04.07.
} 
hez. Megismerkedhetünk a tanulói aktivitásra alapozó tanulásszervezés legfontosabb jellemzőivel, a tanulást támogató, fejlesztő értékelés kulcskérdéseivel, valamint céljai megvalósításának nehézségeivel.

A második fejezet Trencsényi László deltoid modellje felhasználásával a különböző nevelési színtereket rendszerezi, utalva a társadalomban bekövetkező változásokra, az egyén életéhez kötődő helyszínek számának bővülésére, illetve azok tartalmának változására, és mindezen változások nevelést érintő következményeire.

Míg a kötet első két fejezete a fejlesztő értékelés elméleti hátterét ismerteti, addig a további fejezetek az iskolai értékelés ezen új szemléletének gyakorlati megvalósításával foglalkoznak. A harmadik fejezet „a fejlesztő értékelés bevezetése intézményi szinten" címet viseli. A szerzők a nevelés résztvevőit (diák, pedagógus, intézményvezetés, szülö) sorra véve, ismertetik a fejlesztő értékelés előnyeit, mintegy érvelve a fejlesztő értékelés mellett. A Teljesítményért és Fejlődésért az Értékelés Segítségével Társaság (AAIA) ${ }^{2}$ ajánlását követve bemutatják a fejlesztő értékelés bevezetésének főbb lépéseit (elméleti háttér megismerése, stratégia meghatározása, reflexió a gyakorlatra, visszacsatolás a stratégiához), ismertetve a stratégia meghatározásához szükséges, mérlegelendő kérdéseket. Az egyéni értékelési gyakorlat elemzéséhez használható segítő munkalap és kérdések bemutatásán túl a szerzők felhívják a figyelmet a tervezési folyamat, a gyakorlatra való önreflexió és a helyzetelemzés fontosságára.

A könyv lényegi mondanivalóját képező negyedik fejezet a fejlesztő értékelés módszertanának elméletét és gyakorlatát mutatja be. A szerzők sorra veszik a fejlesztő értékelés megvalósítása előtt felteendő kérdéseket (miért és mit értékelünk, ki értékelje és hogyan a tanulói teljesítményeket), valamint a gyakorlati megvalósításhoz hasznos tanácsokkal és konkrét eszközökkel látják el az olvasót. Megismerkedhetünk a szülöi klub szervezésének, az egyéni tanulási mód megismerésének technikáival, és szemléletes mintát kapunk a tanulási napló és a portfólió eszközökre. A szerzők a gyakorlatból vett ,jó példák” bemutatásán keresztül, az egyes eszközök tartalmának és készítési lépéseinek részletes ismertetésével nyújtanak segítséget a fejlesztő értékelés gyakorlatba való bevezetéséhez. A fejlesztő értékelés legföbb törekvése a tanulási folyamat, a tanulói teljesítmények és kompetenciák, valamint a szociális viselkedés fejlesztése. Ennek eléréséhez ajánlott módszerek: a T-kártya, az egyéni beszélgetés, az egyéni tanulási terv és a közös szabályok megalkotásának módszere. A T-kártyára ${ }^{3}$ két példát is bemutat a könyv, külön az általános és külön a középiskolában tanítók számára. A hatékony tanári visszajelzés jellemzőinek ismertetésén túl a szerzők felhívják a figyelmet az önértékelés

\footnotetext{
${ }^{2}$ Association for Achievement and Improvement through Assessment, URL: http://aaia.org.hu Letöltés ideje: 2015. 02. 12.

${ }^{3}$ A kártya T alakú formába rendezve tartalmazza a tanár és diák által közösen kialakított, az értékelendő tevékenységet, ill. produktumot jellemző kategóriákat, és az azokat részletesen leíró értékelési szempontokat.
} 
(társ- és csoportértékelés) fontosságára is. A diákok önértékelési képességének fejlesztéséhez segítő kérdések és önértékelő táblázatok sokaságának bemutatásával nyújtanak segítséget a szerzők.

Az adaptív (a tanulók egyéni szükségleteit figyelembevevő) tanulásszervezés és értékelés módszereiként bemutatásra kerülnek a következő eljárások: a „ne tedd fel a kezed" és a ,jelzőlámpa" módszer, a témazáró teszt tanulói kérdésekből való összeállításának, illetve a helytelen megoldások felhasználásának módszere, valamint az ún. KULCS-kártya (a tanulói teljesítmények rögzítésére szolgáló kártya) alkalmazásának lehetőségei.

Az ötödik fejezet két komplex példát mutat be a fejlesztő értékelés magyarországi gyakorlatából. Az egyik egy gyermekotthonban, a másik pedig a múzeumpedagógiai gyakorlatban alkalmazott fejlesztő értékelési metodika sikereit és nehézségeit ismerteti. A gyermekotthoni példa Bárnai Árpád egy hosszabb hangvételü munkájának rövidített változata, amely valójában még nem egy ténylegesen a gyakorlatban megvalósult módszertant mutat be, hanem az elmélet szintjén maradva, a könyv korábbi fejezeteiben megismert fejlesztő értékelés-elméletnek a gyermekotthonok világában (szabadidős tevékenységek, szakkörök, sportolás, múalkotás, a diákújság szerkesztése, valamint a diákönkormányzat müködése során) fellépő speciális alkalmazási lehetőségéről, a gyermekotthonok életében felhasználható fejlesztő értékelési eszközök felhasználhatóságáról tájékoztat. A második alfejezetben Páll Evelin és Radák Luca munkája olvasható a múzeumpedagógiai foglalkozásokon alkalmazott fejlesztő értékelési módszerek tapasztalatairól. Rövid áttekintést kap az olvasó az új módszer múzeumpedagógiai gyakorlatba való bevezetését sikeresen megvalósító Vízválasztó Vizuális Oktatási Alapítvány (VIVO) müködéséröl, céljairól, a fejlesztő értékelés múzeumpedagógiai alkalmazási lehetőségeinek bizonyítékairól. A szerzők részletesen ismertetik egy, a Magyar Nemzeti Galéria történeti festészet tárlatán korábban lezajlott múzeumi foglalkozás menetét, lépéseit. Három festmény (Madarász Viktor és Orlai-Petrich Soma müvei) középiskolás diákok által történő megtekintése során a képekkel kapcsolatban feltett kérdések, megbeszélt fogalmak ismertetésén keresztül lépésről-lépésre haladva bizonyítják a szerzők a fejlesztő értékelés pozitív hatásait. Céljuk a diákok kritikai hozzáállásának, véleményformálásának, szabad értelmezési lehetőségeinek kialakítása, érdeklődésük felkeltése. A fejezet végén összegzés található a célokról, tapasztalatokról, módosítási és továbbfejlesztési lehetőségekröl egyaránt.

A hatodik - összefoglaló - fejezet kiemeli a mủ korábbi fejezeteinek kulcselemeit, legfontosabb megállapításait, a fejlesztő értékelés, mint új szemlélet bevezetésének igényeit és nehézségeit.

A Módszertár címet viselő hetedik fejezet táblázatszerüen, tömör, jól áttekinthető formában összefoglalja a könyvben bemutatott valamennyi eszközt és módszert, hangsúlyozva az egyes módszerek, munkalapok alkalmazási szempontjait. 
Az utolsó fejezet pedig a könyv megírásához felhasznált szakirodalom felsorolását tartalmazza.

A könyv jól tagolt, a fejezetek, alfejezetek, alpontok a téma logikus felépítését követik. A fogalmak pontos definiálása, a történeti elözmények, tudományos kapcsolódások, a fejezetek elején található, érdeklődést felkeltő összefoglalások, a célok és a témával kapcsolatban felmerülő kérdések tisztázása kellő mértékü elméleti megalapozást adnak a fejlesztő értékelés gyakorlati megvalósításához. Az egyetlen hiányérzetet az olvasóban a fejlesztő értékelés módszerének a felső- és felnőttoktatásban való alkalmazhatóságára tett javaslatok hiánya keltheti. A mü csak az általános- és középiskolai gyakorlatban található ,jó példák” bemutatásával foglalkozik, a szerzőpáros adós maradt annak ismertetésével, hogy a módszer milyen formában használható a fiatal felnőttek és az idősebbek képzési folyamatában.

A mủ a szerzőpáros törekvésének megfelelően egy módszertani füzet, mely a szemléltető ábrák, rajzok és a nagyszámú munkalap bemutatásával a gondolatébresztés, az ötletadás, a módszertani útmutatás feladatát kitünően teljesíti. Az ízléses és igényes tipográfia segíti a jobb áttekinthetőséget, a szövegtől sötétebb árnyalatukkal elkülönülő szemléletes táblázatok és munkalapok a fejlesztő értékelés módszertanával ismerkedők számára kiindulópontul szolgálhatnak az új szemlélet megértéséhez és gyakorlati megvalósításához.

\section{Irodalom}

Báthory Zoltán (1997): Tanulók, iskolák - különbségek. Nemzeti Tankönyvkiadó, Budapest.

Brassói Sándor - Hunya Márta - Vass Vilmos (2005): A fejlesztő értékelés: az iskolai tanulás minőségének javítása. Új Pedagógiai Szemle, 2005. július-augusztus sz. 4-17.

Golnhofer Erzsébet (2003): A pedagógiai értékelés. In: Falus Iván (szerk.): Didaktika. Elméleti alapok a tanitás tanulásához. Nemzeti Tankönyvkiadó, Budapest. 385-416.

Scriven, M. (1967): Series on Curriculum Evaluation. The Methodology of Evaluation. AERA Monograph.

Vidákovich Tibor (2005): Fejlesztö értékelés. A formativ értékelés újrafelfedezése. URL: http://ftp.oki.hu/download/hirek/hirek-konferencia-20050929/abstract-vidakovicht.pdf Letöltés ideje: 2006. január 5.

Lénárd Sándor - Rapos Nóra (2009): Fejlesztő értékelés. Gondolat Kiadó. ELTE PPK Neveléstudományi Intézet, Budapest, 124 oldal 